\title{
The Brazilian House in the Eighteenth Century: Devotion at Home
}

\author{
Cristina Osswald
}

Watch and pray, that ye enter not into temptation.

The spirit indeed is willing,

but the flesh is weak.

MATTHEW 26:41

In this essay, I discuss the striking aspects of domestic devotion or religiosity in eighteenth-century Brazil. I consider virtuous, as well as sinful conceptions of ritual, and how these relate to visible aspects of the design of spaces, and the popularity of certain objects for devotional use. This chronology corresponds to the period when Catholicism was definitively entrenched in Brazil.

It was not until the end of the seventeenth century, once the colony had become established in most of the territory constituting present-day Brazil, that it was possible to enhance and control more strictly the application of the reform vehiculated by priests and laymen knowledge and experience of religious life proclaimed by Trent. I highlight the organization of the Synod in Salvador da Bahia in 1707, leading to the publication in 1720 of the First Constitutions of the Archdiocese of Bahia, the official text applying the Tridentine rules to Brazil [Fig. 1.1]. ${ }^{1}$ Among other topics, the Constitutions of Bahia, as they are normally known, include a compilation of acts then considered particularly serious

1 Constituiçoens primeyras do Arcebispado da Bahia feytas, \& ordenadas pelo Illustrissimo, $e$ Reverendissimo Senhor D. Sebastiaõ Monteyro da Vide, Arcebispo do dito Arcebispado, \& do Conselho de Sua Magestade, propostas, e aceytas em o sinodo Diocesano que o dito Senhor celebrou em 12. de Junho do anno de 1707; (Lisbon, Officina de Paschoal da Sylva, impressor de Sua Majestade: 1719; reprint, São Paulo: 1853).

(C) CRISTINA OSSWALD, 2019 | DOI:10.1163/9789004375888_003

This is an open access chapter distributed under the terms of the prevailing CC-BY-NC-ND License at the time of publication. 


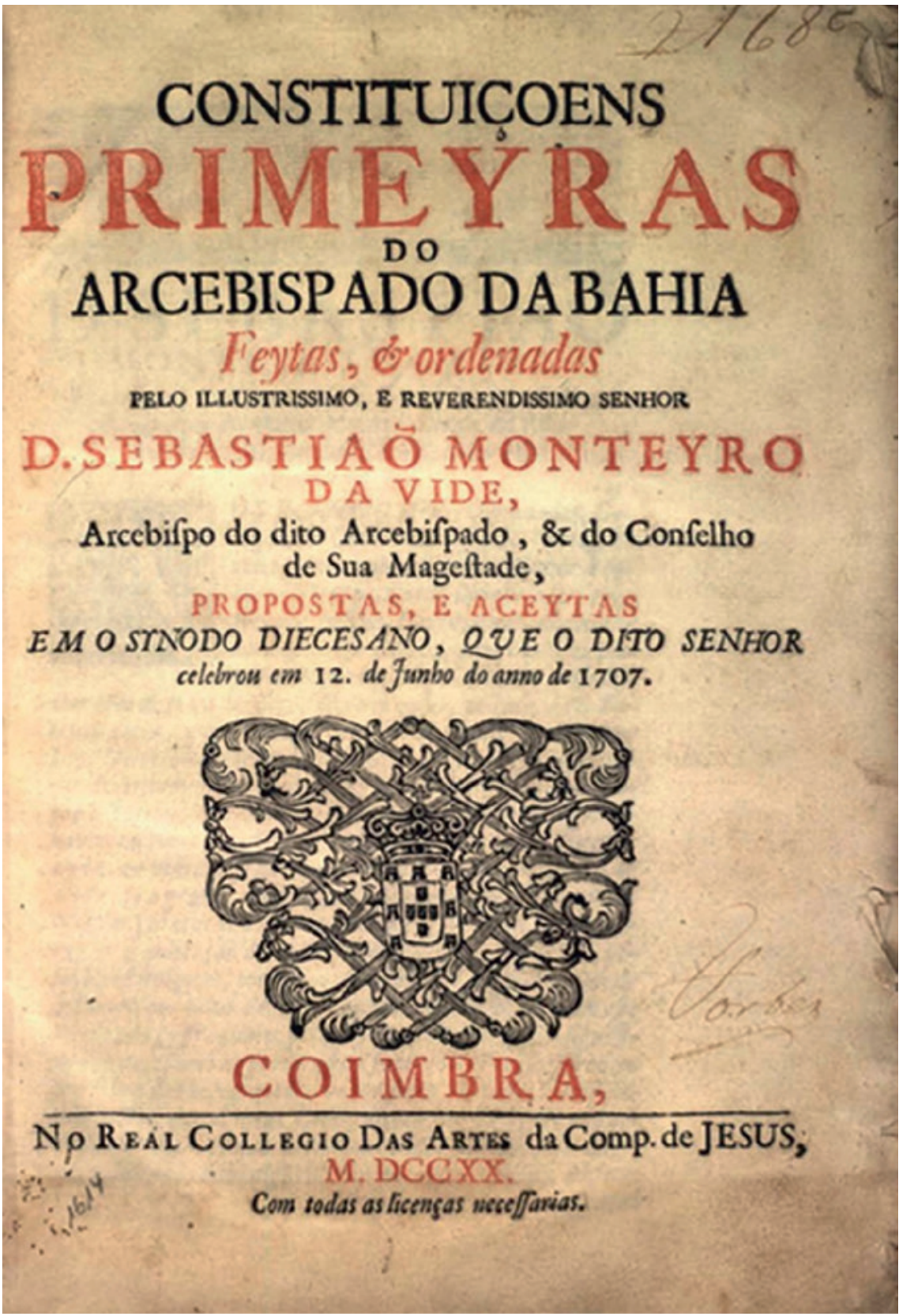

FIgure 1.1 Sebastião Monteiro da Vide, Constituições Primeiras da Arquidiocese da Bahia (Coimbra, no Real Colegio das Artes da Comp. de Jesus: 1720) HTTPS://COMMONS.WIKIMEDIA.ORG/WIKI/FILE:CONSTITUI\%C3 \%A7\%C3\%B5ES_PRIMEIRAS_DO_ARCEBISPADO_DA_BAHIA.JPG 
'crimes' against religion and the punishments applicable to them. Crimes of heresy, such as pacts with the devil, sorcery or even witchcraft, were punishable by excommunication. ${ }^{2}$

This study is especially interesting given the miscegenated population of Brazil that professed a variety of religions. It is chiefly in the home that we can consider the existence of any predictable deviations from the norm, given that there are greater opportunities to conceal such deviations from the authorities behind closed doors.

Religion could be seen everywhere in the design and use of space in many eighteenth-century Brazilian homes. A family's connection to a specific devotion was already visible outside their house in the form of a cross or of a flag bearing the respective iconography, which was also displayed in the communal areas. ${ }^{3}$

The popularity of certain devotions always reflects impositions by authorities. Drawing on the significant increase in printing during the Enlightenment, the Church sought to disseminate uniform rules for devotion, including the fostering of certain cults. For instance, the work Mestre da vida que ensina a viver e morrer santamente by the Dominican friar João Franco, which was so popular from the mid-seventeenth century until the end of the eighteenth century that it was reprinted seventeen times, includes the following series of instructions concerning the devotion to Christ and Mary to be followed by Catholics over the course of the day. In the ritual proposed by the author, the devout Catholic was to start his or her day by crossing him or herself and saying three Hail Marys while still in bed. While dressing he or she was to recite Christological prayers. And as soon as he or she had dressed he or she was to kneel before an image of Christ. ${ }^{4}$

In this epoch, domestic ritual and devotional paraphernalia honoured Christ and Mary in particular, and these were the two most important cults within Catholicism in Portugal as well. The special attachment of eighteenth-century

2 Constituiçõens Primeiras do Arcebispado da Bahia, book v, chapter IV 314-315, 322.

3 Mott L., "Cotidiano e vivência religiosa: entre a capela e o calundu", in Novaes F.A. - Souza L.M. (eds.), História da Vida Privada no Brasil, Cotidiano e vida privada na América portuguesa (São Paulo: 1997) 156-220, here 164.

4 Franco João, Mestre da vida, que ensina a viver, e morrer santamente (Lisbon, Na Regia Officina Typografica: 1750) 1-2. 
Brazilian households to the Passion is inferred at first glance from the spread of crucifixes.

At the beginning of the nineteenth century, the English visitor John Luccock wrote:

Returning from a short ramble, in the cool of the evening, I found the family at vespers. [...] The doors of the oratory remained open, and the Crucifix exposed, until supper was just about to be served in the same room. The master then approached the sacred insignia, with great seriousness, made a profound bow to the image, and closed the doors. ${ }^{5}$

Indeed, the presence of private altars with images of Christ on the Cross with Mary, St Joseph and St Anne indicated the family's importance. ${ }^{6}$

Another important Christological trend was the existence of ex-votos painted in the eighteenth century, thanking Our Lord of Matosinhos for salvation from shipwrecks and healing from illnesses. This cult was taken by Portuguese sailors from North Portugal, and reached its peak in Brazil with the construction of the Sanctuary at Congonhas, Minas Gerais, between 1757 and 1875 [Fig. 1.2]. ${ }^{7}$

Still at the beginning of the nineteenth century, the English traveller Gilbert Farquhar Mathison marvelled at the habit of the farmer Joaquim das Lavrinhas, of Cantagalo in Rio de Janeiro State, of kneeling with all those around him, both morning and night before a portable altar in the main room, to ask for God's blessing and the protection of the Virgin Mary. ${ }^{8}$

5 Luccock J., Notes on Rio de Janeiro, and the Southern parts of Brazil: taken during a residence of ten years in that country, from 1808 to 1818 (London: 1820) 445.

6 Branco M.A.H.S.C., "Oratórios Mineiros D. José I: O tema cristológico nos objetos de devoção familiar produzidos entre o fim do século XVIII e início do XIX", in Atas do IV Congresso Internacional do Barroco Ibero - Americano (Belo Horizonte: 2008) 1056-1061, 1059.

7 The designation ex-votos applies to two sorts of objects for private devotion. It refers to images made of wood, clay or wax representing parts of the body whose healing was attributed to a special devotion to Christ, or to the Virgin Mary, or to a saint. It also applies to the small paintings on wood, called tabuletas in Brazil, depicting a miraculous cure, or salvation from a shipwreck, an accident or during a battle. For these reasons, they were also known as milagres. On painted ex-votos given to Our Lord of Matosinhos in thanks for healing and for salvation from shipwrecks, see Cunha M.S., Estórias de dor esperança e festa: o Brasil em ex-votos Portugueses (século XVII-XIX) (Lisbon: 1998); Scarano J., Fé e milagre: ex-votos pintados em madeira: séculos XVIII e XIX (São Paulo: 2004).

8 Mathison G.F., Narrative of a Visit to Brazil, Chile, Peru and the Sandwich Islands During the Years 1821 and 1822. With miscellaneous Remarks on the Past and Present State, and Political Prospects of Those Countries (London: 1825) 105-107. 


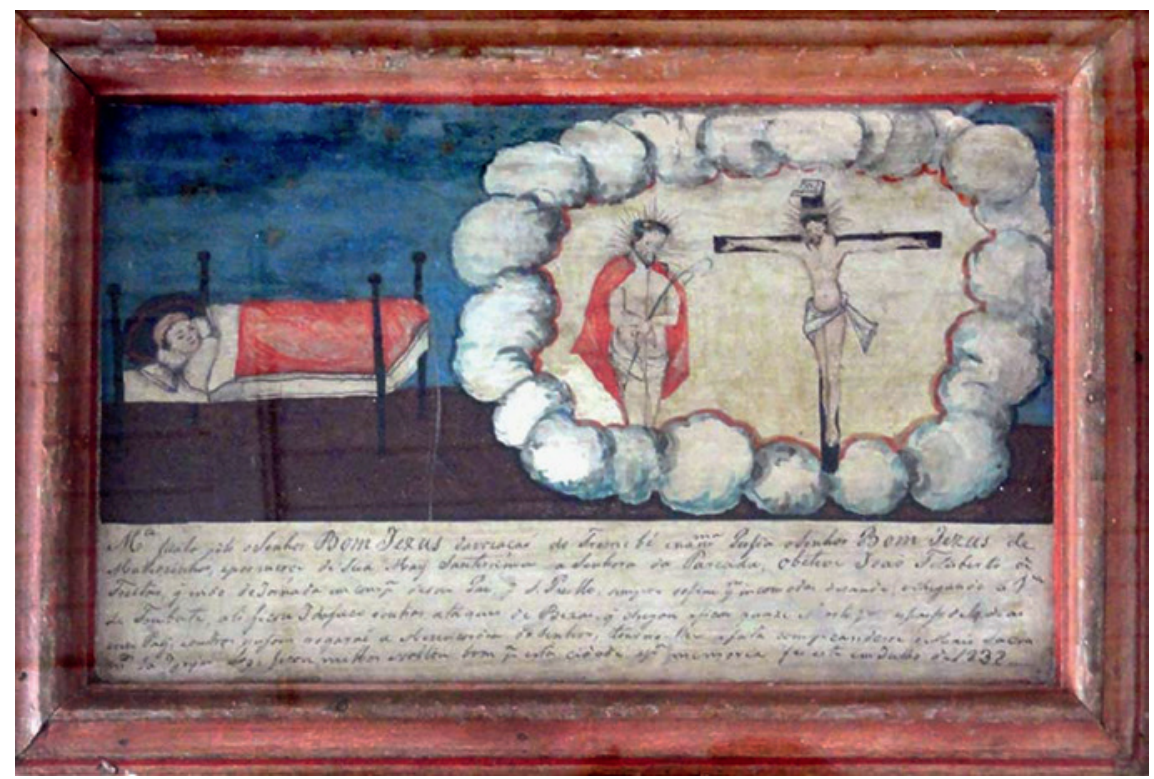

FIGURE 1.2 Ricardo André Frantz, Ex-voto expressing the gratitude of a healed pearson to the Bom Jesus de Matosinhos, 1832, Santuário de Congonhas, Minas Gerais HTTPS://COMMONS.WIKIMEDIA.ORG/WIKI/FILE:EX-VOTO_-_SANTU\%C3 \%A1RIO_DE_CONGONHAS_-_S\%C3\%A9CULO_XIX.JPG. CONSULTED ON THE 12TH JULY 2016

Underlying the importance of the Marian cult in Brazil is the special cult dedicated to the Virgin Mary, dating from the foundation of Portugal, and which grew with the expansion of the Portuguese Empire. The latter aspect was exemplified by the Brazilian Marian cult of Nossa Senhora da Aparecida, patroness of Brazil, and whose cult dates to 1717 - when some fishermen in Paraiba were finally blessed with an abundant catch after an image of the Immaculate Conception fell into their nets.

The affectionate, intimate relationship Brazilians had with the Virgin Mary began at the moment of their initiation as Catholics, as thousands of Brazilians were given the Holy Virgin as Godmother. That relation was given sacramental force by putting a crown or a royal stick on the head of the baptized child. ${ }^{9}$

9 Mott, "Cotidiano e vivência religiosa" 185 . 
In Brazil Marian devotion was particularly popular among women. Frei Agostinho de Santa Maria wrote in the Santuário Mariano that the mantle of Nossa Senhora do Parto (Our Madonna of Parturition) of the Cathedral of Bahia had special powers over complicated births. ${ }^{10}$

At the time, the custom was for people to be born at home. All over Brazil an image of Our Lady of Parturition was placed by the beds of women giving birth, and a Marian crown was placed on the child's head at baptism. ${ }^{.1}$ The success of this devotion may be explained by the high mortality rate among parturient women and newborn babies.

Interiors and domestic religious rituals reflected the devotions of the main orders - Jesuits, Franciscans, Carmelites and Benedictines - at the local level. In particular, St Francis Xavier ranked among the more venerated saints and members of the orders. This prominence can be explained not only by the fact that Francis Xavier was the most distinguished Early Modern missionary, but also by the leading role played by the Society of Jesus in Brazil, in terms both of geographical spread and of numbers. The Jesuits were the largest group of missionaries in Brazil, and were spread over a greater area than all other Catholic orders. They were, moreover, the first Catholic order to establish itself on a permanent basis upon arrival in Brazil in 1549 .

The cult of the Franciscan St Anthony of Lisbon deserves special mention as well. The intercession of this saint, known affectionately in Brazil by the diminutive Sant'Antoninho, was popularized through figurines that were hung around the wearer's neck. As in Portugal, so in Brazil prayers to Sant'Antoninho seemed particularly effective in romantic encounters and marriages, and for finding lost objects. However, his intercession was also sought in all sorts of tribulations. Specific to Brazil was the saint's reputation as someone who helped slaveholders to find escaped slaves. ${ }^{12}$

Nuno Marques Pereira observed enthusiastically that a black captive called Manoel had an altar with images of Christ, Our Lady of the Rosary, and other saints at home. I suggest that Manoel was probably a member of a confraternity or brotherhood of the rosary. He and his family sang the rosary every day. Then, we read in the same account that Manoel had the first vote in the

10 Santa Maria Agostinho de, Santuario Mariano, e Historia das Image $[n] s$ milagrosas de Nossa Senhora, e das milagrosamente apparecidas, em graça dos Prègadores, \& dos devotos da mesma Senhora, 20 vols. (Lisbon, Na Officina de Antonio Pedroso Galrão: 1707-1723; reprint, Lisbon: 1933) vol. 9, 9-11.

11 Vianna H., A Bahia já foi assim (crônicas de Costumes) (São Salvador da Bahia: 1973) 19-20.

12 Mott, "Cotidiano e vivência religiosa" 187-189. 
elections of the confraternities and brotherhoods, due to the zeal with which he served God and Our Lady of Rosary in the mother church. ${ }^{13}$

This observation introduces the next point: that Brazilian houses reflected the devotions and iconographies that were proper to the third orders and that were related to the affirmation of Afro-descendants in Brazilian society. The popularity of the black and pardo confraternities and brotherhoods who honoured black saints like St Benedict of Palermo, St Iphigenia or St Elesban, constitutes an expression of social mobility among members of Afro-descendant communities in the Iberian world in the eighteenth century [Fig. 1.3].14 According to the researcher of Brazilian brotherhoods Caio César Boschi, these cults responded mainly to private needs. The black saints were cults of Afro-descendant people not only due to the affinity of skin colour and geographic origin, but also to similar life trajectories. The 'saints of the white people' would hardly understand the suffering of black slave people. ${ }^{15}$

\section{The Role of Religion in the Definition of Domestic Space and} Behaviour

In addition to the religious communities of friars and nuns who followed strict rules, we can trace an extremely radical form of austere religious experience, as exemplified by a number of cloistered communities of young women, the beatas. Unlike travelling beatas or missionaries, cloistered beatas lived with families or in beatérios, non-institutional communities of women. ${ }^{16}$ This was the case of the two sisters Maria de Castro and Beatriz da Costa, who spent most of their lives in perpetual enclosure at their parents' home, weakening their bodies by continuous fasting, scourging themselves, and spending night and day in continuous prayer. We also know the stories of other young women who spent most of the day praying, at times crying in front of altars, and whose

13 Pereira Nuno Marques, Compendio narrativo do peregrino da America em que se tratam varios discursos Espirituaes, e moraes, com muitas advertencias, e documentos contra os abusos, que se achão introdusidos pela malicia diabolica no Estado do Brasil. Dedicado à Virgem da Vitória, emperatris do ceo, rainha do mundo, e Senhora da Piedade, Mãy de Deos, 2 vols. (Lisbon, Officina de Manoel Fernandes da Costa, Impressor do Santo Officio: 1728; reprint, Lisbon: 1939) vol. 1, 152.

14 Rowe E., "Visualizing Black Sanctity in Early Modern Spanish Polychromic Sculpture", in Patton P.A. (ed.), Envisioning Others: Race, Color, and the Visual in Iberia and Latin America (Leiden - Boston: 2015) 65 .

15 Boschi C.C., Os leigos e o poder (São Paulo: 1986) 26.

16 Almeida S.C.C., O sexo devoto: normatização e resistência feminina no império português, XVI-XVIII, Ph.D. dissertation (Universidade Federal de Pernambuco: 2006) 268-269. 


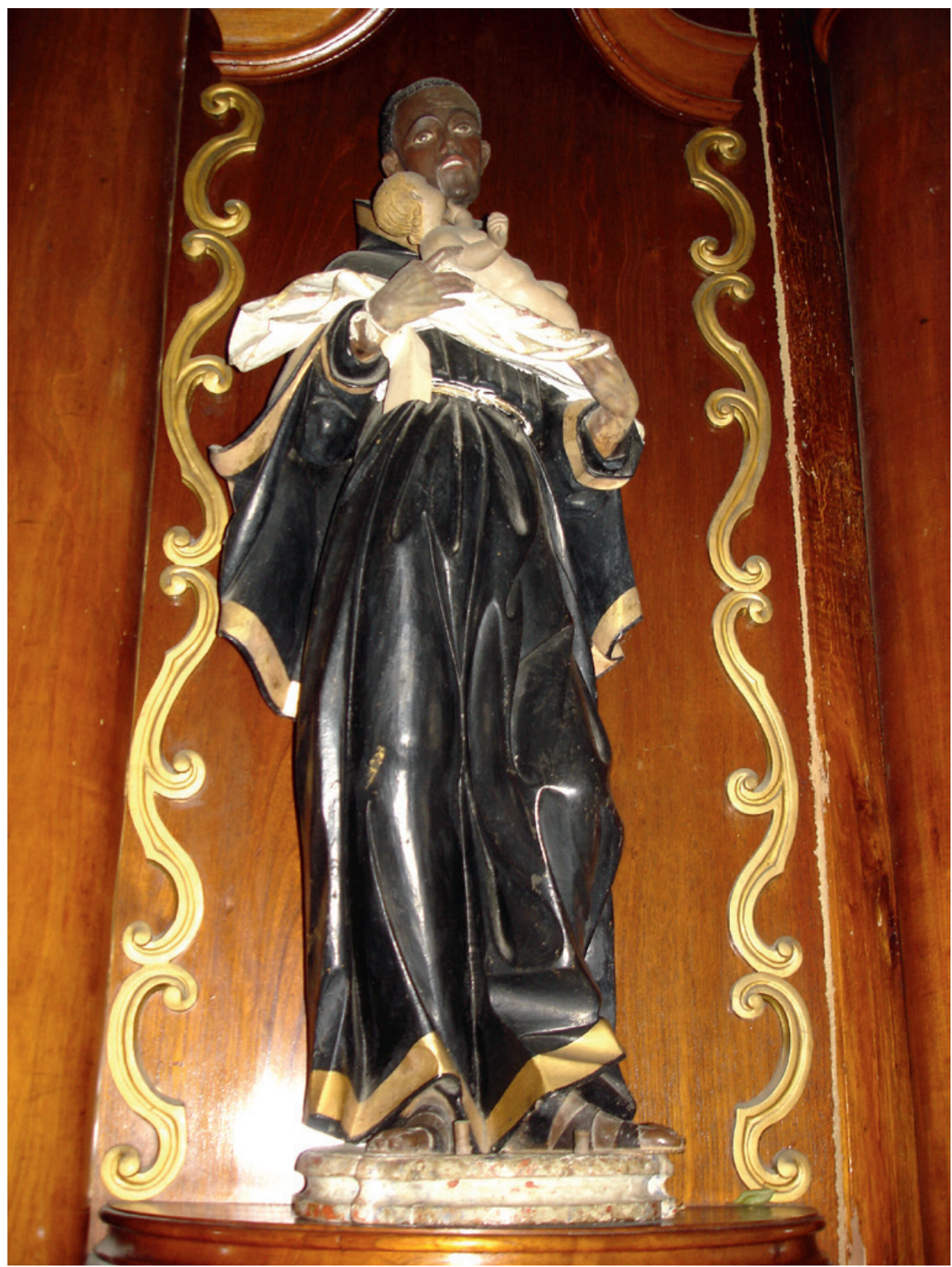

FIGURE 1.3 Unknown artist, Sculpture of Benedikt of Palermo, painted wood, 18th century, Convento de Nossa Senhora do Amparo - São Sebastião, São Paulo PHOTOGRAPHIC CREDITS: FREI RÓGER BRUNORIO, CONVENT OF SAINT ANTHONY, RIO DE JANIERO 
contact with the outside world was limited to going to Mass. Several of them were distinguished with visions, which were more common among women than men. ${ }^{17}$

According to the contemporary conception of Catholicism, practices of penitence and of retreat were essential aspects of the life of both religious and lay people. Illustrating this acknowledged viewpoint, Francisco da Conceição, one of the most distinguished theologians in eighteenth-century Brazil, prescribed that the devotee should make one day's retreat each month, make an annual retreat of between eight and ten days, fast on Fridays and Saturdays, self-flagellate three times a week, and wear a cilice for two hours also three times a week. ${ }^{18}$

During the eighteenth century, the majority of the population of Brazil lived in small villages and isolated rural households, of which the most characteristic were the fazendas and the engenhos. Whereas the fazendas could have a variety of economic functions - agricultural manufacturing and fishery - the engenhos were dedicated solely to the production of sugar. The latter were the most apparent element of the Sugar Cycle. ${ }^{19}$ This rural lifestyle meant that even ceremonies and events that were customarily public were, in colonial Brazil, for the most part celebrated within a smaller circle of people. In addition to the spread of the celebration of domestic Mass, such religious highpoints of the Catholic calendar as Christmas or Easter involved setting up altars, and organizing processions, religious theatres, musical performances, dances and

17 Algranti L.M., "A hagiografia e o ideal de santidade feminina: o impacto da leitura de vidas de santos nos conventos do Brasil colonial", in Silva M.B.N. (ed.), De Cabral a D. Pedro: Aspectos da Colonização Portuguesa no Brasil (Oporto: 2001) 171.

18 Conceição Francisco da, Director instruído ou breve resumo de mística teologia para instrução dos directores (Coimbra, Na Real Imprensa da Universidade: 1779) 465.

19 The term Sugar Cycle designates the period of the history of Colonial Brazil running essentially between the middle of the sixteenth and the middle or the end of the seventeenth century, according to the different authors. This designation derives from the fact that sugar was the main product of colonial Brazil, in particular of Bahia and Pernambuco, during this period. The Sugar Cycle was followed by a period coined the Gold Cycle. The later was the period in Brazilian colonial history marked by the exploration of gold and precious stones, chiefly in Minas Gerais state. This period, which began with the discovery of the mines in Taubaté in the 169os, reached its peak in the 1750 s and 1760 s and lasted until around 1785 , with the start of the Industrial Revolution in Great Britain. (Baer W., A economia brasileira (S. Paulo: $2009^{3}$ ) 356; Eisenberg P.B., The Sugar Industry in Pernambuco: Modernization Without Change, 1840-1910 (Berkeley 1974) 4; Russell-Wood, A.J.R., "The Gold Cycle, c. 1690-1750", in Bethell L. (ed.), Colonial Brazil (Cambridge et al.: 1987) 190-243. 
balls of slaves or indigenous people, either in the houses or in front of them. ${ }^{20}$ Furthermore, during the laying of the cornerstone of a wealthy house the stone was blessed with holy water, and important dates in the annual calendar were marked by religious rituals. For instance, a priest blessed the engenhos on the first day of the grinding of sugar cane, the so-called botada. ${ }^{21}$

This domestication of ritual obviously had important effects on the use of space. From the seventeenth century onwards it became fashionable to build private chapels, either attached to houses or in separate buildings, inspired by the solares of noblemen in Portugal, also built from the seventeenth century onwards [Fig. 1.4].$^{22}$ In rural Brazil these chapels acquired special significance. They often symbolized the social discrimination that was prevalent since they allowed the elites to attend Mass at home, without having to mix with the rest of the population. We even know of chapels surrounded by steps and lattices assuring the seclusion of the worshippers at Mass.

By contrast, however, some domestic chapels were attached to verandas or located on them. These chapels allowed all members of the household, including servants and slaves, as well as visitors, to participate in religious ceremonies. Mass and other collective rituals could be also celebrated in front of simple altars placed on verandas and in other communal areas such as living rooms and entrance halls. Some wealthier households also had a 'saints' room', which could range in size from a chamber or a small area for religious practice to a simple space beneath a staircase or in the basement.

Strong religiosity, a distinctive mark of many Brazilian households at the beginning of the eighteenth century, was expressed in the proliferation of a range of objects for private worship which surrounded inhabitants and visitors in the houses of good Catholics from morning till night. On waking up, the first things the faithful would see would be a small picture honouring Christ, Our Lady or a saint that hung on the wall, a rosary and a crucifix on the bedhead.

20 Silveira J. de S.J.Q. da, "Viagem e Visita do Sertão do Bispado do Gram Pará em 1762 e 1763", Revista do Instituto Histórico Geográfico Brasileiro 9 (1847) 43-106, 179-227, 328-375, 476-527, here 106; Souza L.M., "Formas provisórias de existência: a vida quotidiana nos caminhos, nas fronteiras e nas fortificações", in Novaes - Souza (eds.), História da Vida Privada 42-81, here 59.

21 Jancsó I., "A sedução da liberdade: cotidiano e contestação política no final do séc. XVIII", in Novaes - Souza (eds.), História da Vida Privada 388-437, here 416.

22 Solar means a large house or palace, generally built by a noble family, with its own chapel. In Portugal, solares were found mainly in the region of Entre Douro and Minho, the source of the oldest Portuguese aristocracy and an area that also accounted for most of the Portuguese emigrants to Brazil before and after independence was declared in 1822 . 


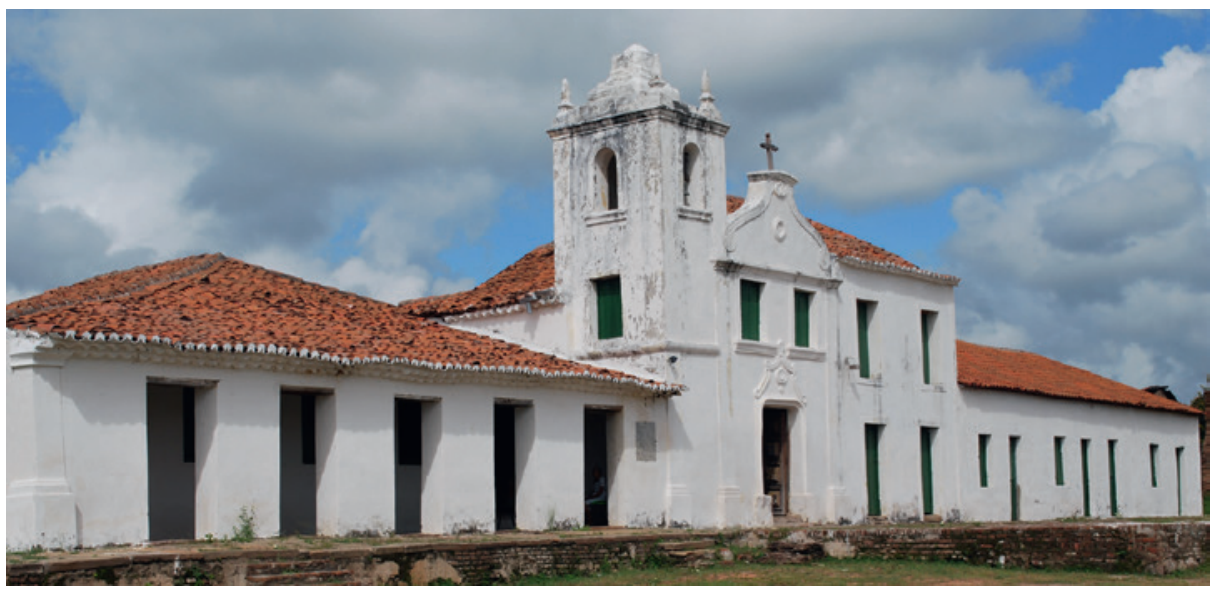

FIGURE 1.4 Fazenda of Acuã, Aparecida, Paraiba, second half of the 18th century PHOTOGRAPHIC CREDITS: A. SILVA

The images, in particular registos, ${ }^{23}$ crucifixes and even bowls of holy water in bedrooms were intended to protect their occupants while they slept and also remind them that death and disease often accompany sleep. This array of objects was complemented by lit votive lamps, images decorated and dressed by women, miraculous medals, scapulars and prayer books.

Communal areas, such as dining or living rooms, contained many pictures of the saints to whom the family was particularly devoted, crucifixes, and also small private altars on tables and dressers or niches with images in the walls. Saints were considered family members! Portraits of dead family members were often kept among the images of saints.

Some talismans accepted by the Church were kept in the saints' room. When a woman went into labour, if a rose of Jericho inside a glass of water opened quickly, this signified that the birth would go well, if the rose did not open this signified death. The blessed straw from Palm Sunday was a common object in the saints' room and was believed to protect the inhabitants of the house from lighting and tempests. Miraculous medals, scapulars and all sorts of religious books were likewise standard objects found in this room.

From the middle of the eighteenth century a fashion spread for small images and altars for individual use, around $10-20 \mathrm{~cm}$ in height, made from

23 Small images for private worship representing a saint/special devotion or a miraculous episode, such as cures, healings and salvation from shipwrecks, and which were very popular in the Portuguese 'world' during the eighteenth century. 


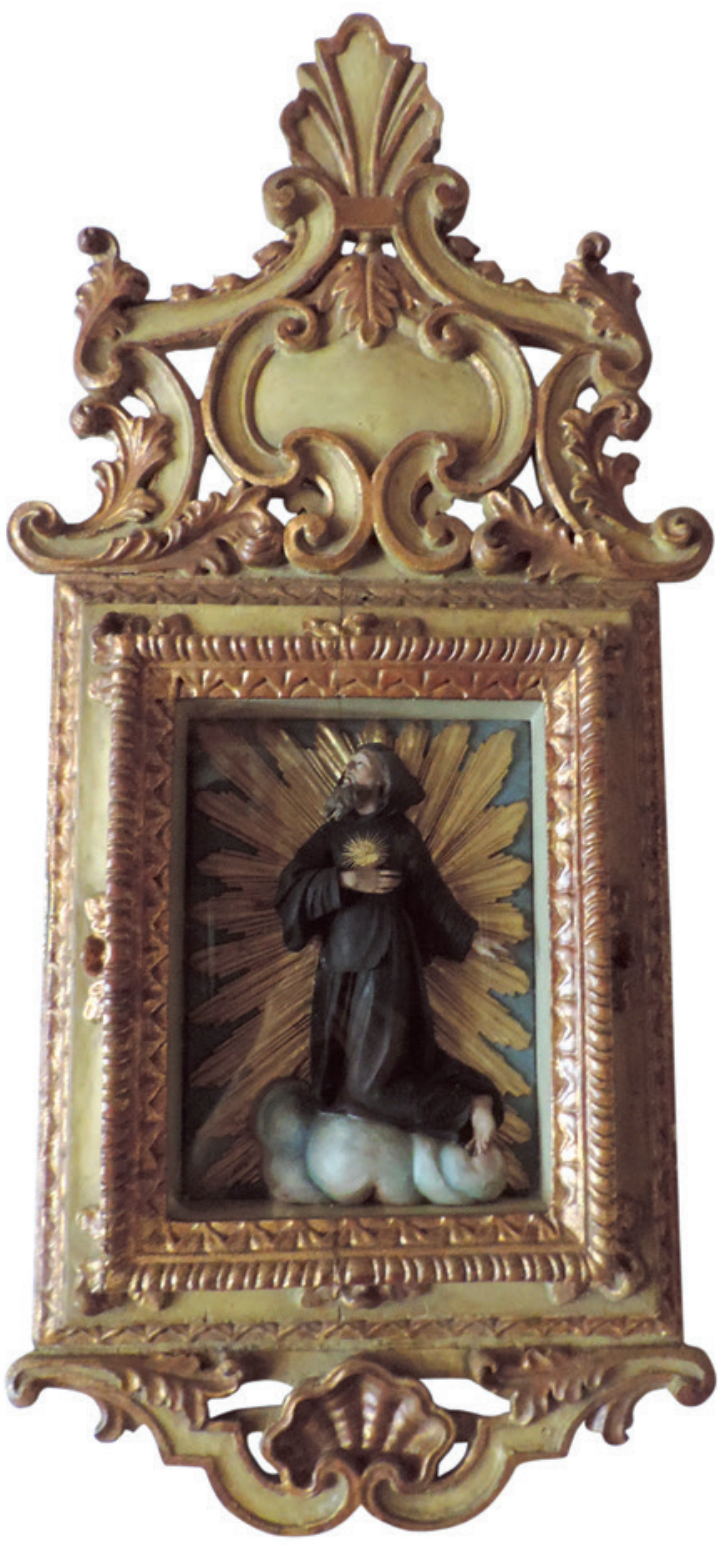

FIGURE 1.5

Unknown artist, Portable Oratory of Saint Francis of Paula also called maquineta or lapinha, Golden wood, 18th century, Convento de Santo António, Rio de Janeiro PHOTOGRAPHIC CREDITS: FREI RÓGER BRUNORIO, CONVENT OF SAINT ANTHONY, RIO DE JANEIRO 


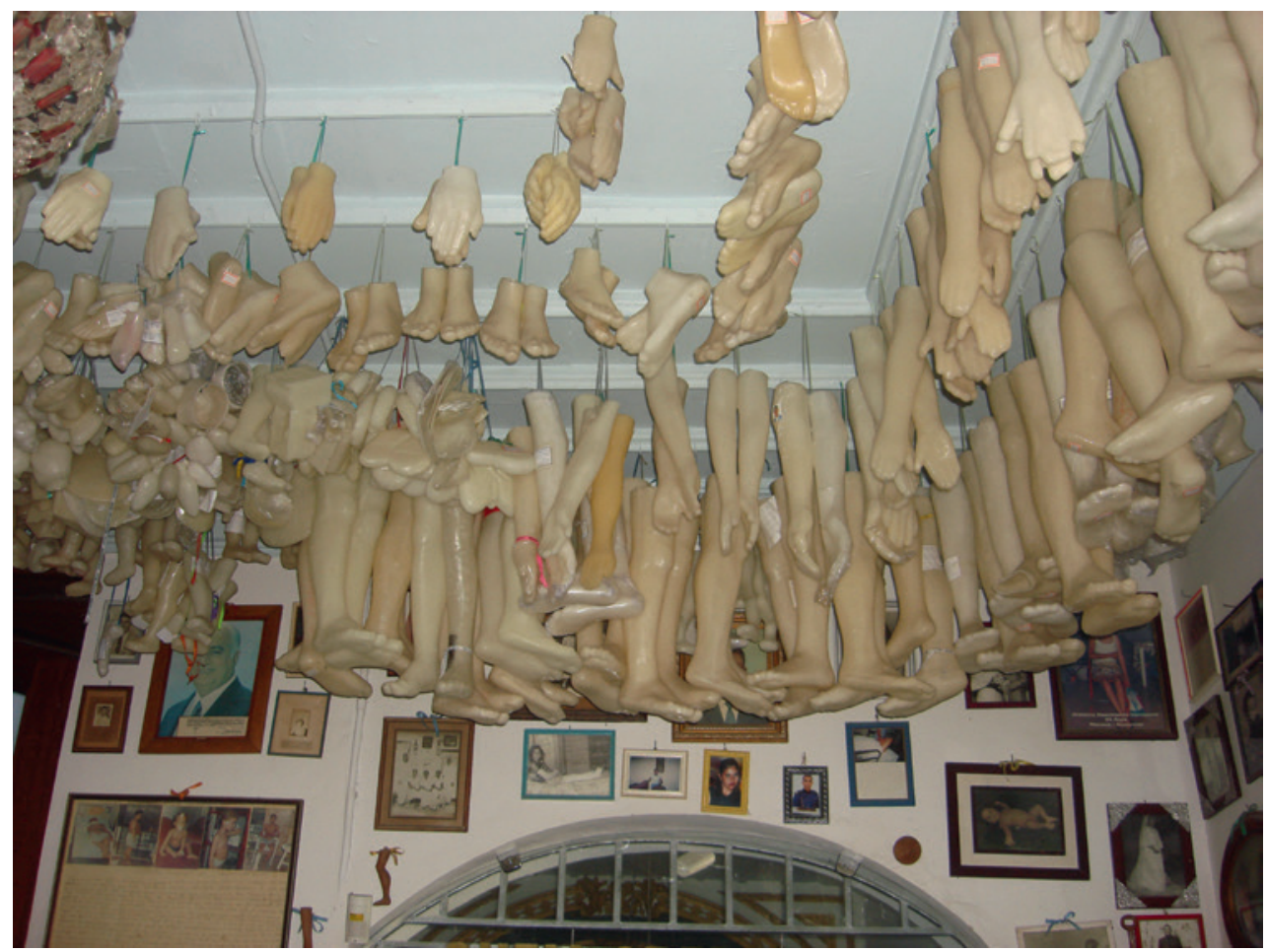

FIGURE 1.6 Ex-votos, Igreja do Senhor do Bonfim, São Salvador da Bahia. Photo of the author, August 2012

soapstone or terracotta, since these could be transported easily by travellers. These altars, also known as maquinetas or lapinhas, were made in Minas Gerais State [Fig. 1.5].

The widespread Baroque sentimentalism that existed across the whole of Brazilian colonial society was also reflected in the domestic setting in the large quantity of relics of sacred and divine figures, such as fragments of bones or of the True Cross, and in the popularity of ex-votos [Fig. 1.6]. ${ }^{24}$

24 Mott, "Cotidiano e vivência religiosa" 164, 166-167. 
An engraving depicting the interior of a farmer's family home by the German painter Johan Moritz Rugendas, who lived in Brazil from 1822 until 1825, gives an idea of how limited domestic privacy could be. Sharing the same room are a lady lying down, a musician, a priest and a number of slaves. One of the slaves announces the arrival of a visitor in the doorway. ${ }^{25}$

The same engraving also relates to the overlapping of functions, both religious and profane that prevailed among Brazilian family aggregates until the nineteenth century. This engraving is further useful to illustrate the fact that the great distances and sparse settlement meant strangers, including priests, were an almost constant presence in the Brazilian home. They often remained for extended periods. ${ }^{26}$

This led to all sorts of activities that were alien to correct Catholic practices, such as celebrating Mass and distributing the sacraments in domestic spaces using non-sacred liturgical objects. In particular, letting women make their confessions at home was considered especially dangerous, as this practice could facilitate the solicitation of sexual favours by clerics, a common sin in colonial Brazil, as can be read in the reports of the three Inquisition visitations which took place respectively between 1591 and 1593,1618 and 1619 , and 1750 and $1777 .{ }^{27}$

Daily life in colonial Brazil was marked by an intense social life, including receptions with banquets, concerts, and dances, and the playing of card games and table games such as backgammon and chess [Fig. 1.7]. Parties are, by definition, ideal moments for games of seduction and the excessive consumption of alcohol, and therefore posed a threat to discipline when parties were attended by clergymen. For this reason, in April 1780 D. Frei Domingos da Encarnação Pontével (1780-1793), the second Bishop of Minas Gerais, ordered the publication of the following notice in Vila Rica, the city of Ouro Preto:

Como seja escandaloso e totalmente alheio do estado eclesiástico que pessoas adidas da Igreja se achem assistindo em ajuntamentos, e atos públicos em que se fazem representações profanas de imensuráveis

25 Rugendas, Johan Moritz, Família de Fazendeiros, watercolour from ca. 1825, in Lima H.L. - Castro R.R., "O imaginário da cristandade no Rio de Janeiro do século XIX nas pinturas de Rugendas e Debret”, 19 \& 204 (2009), http://www.dezenovevinte.net/obras/ obras_cristandade.htm; accessed 8 July 2016.

26 Algranti L.M., "Famílias e Vida Doméstica", in Novaes - Souza (eds.), História da Vida Privada 83-154, here 87, 102.

27 Siqueira S.A., A Inquisição Portuguesa e a Sociedade Colonial (São Paulo: 1978) 55-56. 


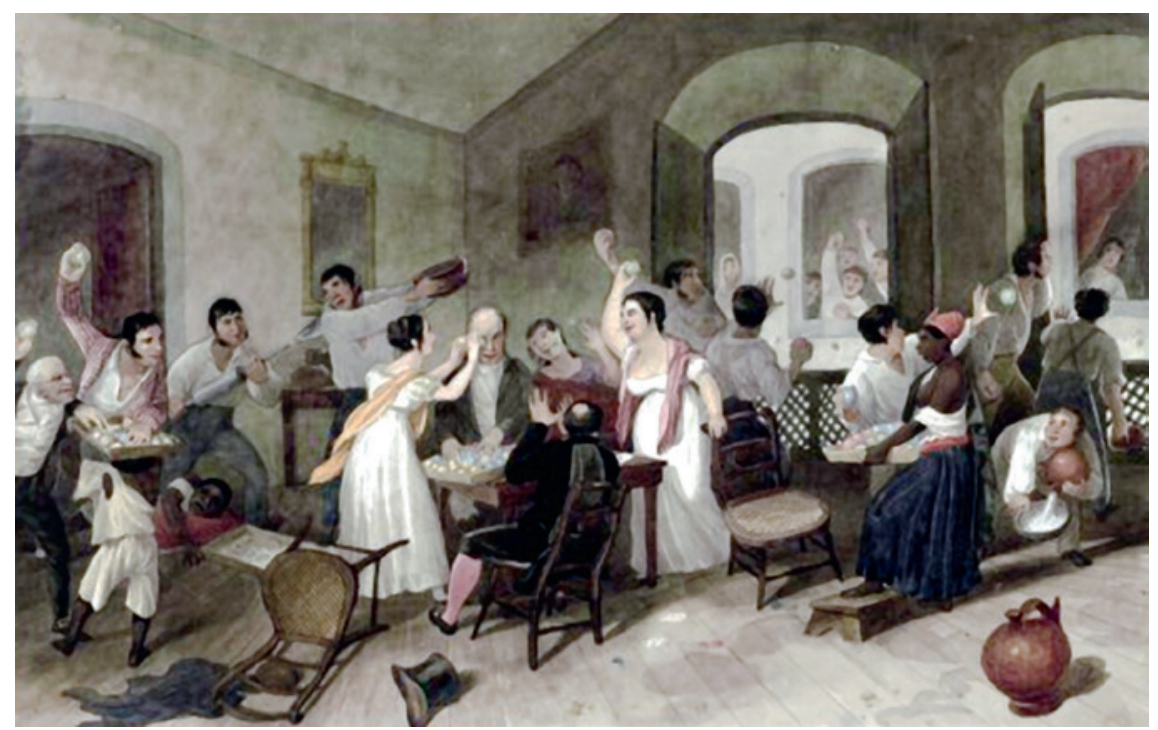

FIGURE 1.7 Augustus Earle, Games During the Carnival at Rio de Janeiro. Watercolour; $21.6 \times 34 \mathrm{~cm}$

SOURCE: NATIONAL LIBRARY OF AUSTRALIA. HTTPS://COMMONS.WIKI MEDIA.ORG/WIKI/FILE:GAMES_DURING_THE_CARNIVAL_AT_RIO_DE_ JANEIRO.JPG. CONSULTED ON THE 12TH JULY 2016

perigos, e que só servem [para] arruinar as almas, e mais fins funestos que deles se seguem. Sendo nós informados que nessa Vila há casa em que se fazem estes ajuntamentos e se representam semelhantes atos, querendo de algum modo obviar a ruína assim espiritual como temporal que se pode seguir aos nossos súditos [...] pelo que ordenamos [...] a cada um dos eclesiásticos [...] que se abstenham de ir a semelhantes atos ainda estando $[\ldots]$ com o pretexto de tocarem instrumento, cantarem.

How scandalous it is, and how totally alien to the ecclesiastical state that persons associated with the Church should attend gatherings and public events at which profane representations are made of immeasurable danger, and which serve only to ruin souls, resulting in further nefarious consequences. Being aware of the fact that in this town there is a house in which these gatherings take place and in which similar acts are performed, and wishing in some way to obviate both the spiritual and temporal ruin which our subjects could incur $[\ldots]$ we therefore order $[\ldots]$ all 
priests $[\ldots]$ to refrain from attending such events even [...] with the pretext of playing a musical instrument or singing. ${ }^{28}$

A common sacrilegious practice was the disrespectful use of sacred objects of worship. However, the possession of devotional items could in itself illustrate the intent to expiate one's sins. Profits obtained from war or from the exploitation and slavery of both Indians and Africans and Afro-descendants were often used to fund art and objects Dei laudem as a means of expiating one's sinful actions.

Sacrilege took the form of a series of practices which consisted of an overly personalized view of worship and which were therefore condemned by the Church authorities. Frei Agostinho de Santa Maria complained about the custom among devout women of plucking the infant Jesus from the arms of sculptures of St Anthony or of removing the saint's halo. The women only returned the infant Jesus and the halo after obtaining a miracle. ${ }^{29}$ When St Anthony or St Gonzalo did not fulfil the wish of the devotee, their images were put inside a well as punishment. ${ }^{30}$

Another widespread practice, which was equally unacceptable to the Catholic authorities, was the custom of carrying or holding onto consecrated hosts, removed from the mouth at Easter communion, as a protection against the great probability of a sudden violent death. ${ }^{31}$

However, the sin was even greater when objects intended for Catholic worship were used for sacrilegious purposes. This seems to have been the case of Maria Carvalha, an inhabitant of recife. In 1762 she was denounced to the Inquisition for allegedly having permitted her daughters to imitate the celebration of Mass before an altar in her home. A number of years later, at the beginning of the 1770s, it was said that the mulata woman Ana Jorge, an inhabitant of Mariana, committed the terrible sacrilege of placing images of the saints under her bed before trysts with her lovers. ${ }^{32}$ In Minas Gerais, as in Lisbon, prayers were dedicated to the milk of Our Lady, which was often in powdered form, and considered to be a powerful instrument against the traps of the devil. As is still the case today, acts of aggression against, and profanation of sacred

28 "Edital de D. Frei Domingos da Encarnação Pontével em Abril de 1789", in Oliveira A.C., "A difusão da doutrina católica em minas gerais no século XVIII: análise das pastorais dos bispos", História: Questões \& Debates 36 (2002) 189-217, here 198.

29 Santa Maria Agostinho de, Santuario Mariano vol. 10, 9-10.

30 Del Priore M., "Ritos da vida privada", in Novais - Souza (eds.), História da Vida Privada no Brasil 275-330, here 315.

31 Silva B.N., Cultura e Sociedade no Rio de Janeiro (1808-1821) (São Paulo: 1977) 333.

32 Mott, "Cotidiano e vivência religiosa" 167, 190. 
images - including spitting on them, beating or burning them, throwing faeces at them and urinating on them - were regarded as especially heinous. ${ }^{33}$

\section{$5 \quad$ Religious Syncretism and Heresy in the Domestic Context}

Heresy can be defined as a belief and religious practice that sharply contradict established religion. As concerns colonial Brazil, non-Catholic practices were mainly related to the presence of New Christians, as well as to the Indian and African communities.

In Portugal, the forced conversion of local Sephardic Jews was ordered by King D. Manuel I in 1497. A decree dated 25 May 1773 and issued by King D. José abolished the distinction between New Christians and Old Christians in the Portuguese Empire. This document officially ended a long period of 275 years of religious and social persecution of the community of New Christians who had moved to Brazil after the arrival of the first Portuguese settlers. Gaspar da Gama, who arrived with the fleet of Pedro Álvares Cabral, is the first known New Christian to arrive in this area. He was immediately followed by many other New Christians, who undertook all sorts of activities, from business to agriculture. Some even entered the priesthood to prove they were not of Jewish blood.

In colonial Brazil, Jewish rituals were the main form of heresy, as evidenced by the fact that they were registered in half of the trials of the Inquisition. Of the 550 inventories of the property of New Christians from the seventeenth and eighteenth centuries studied by Isabel Drummond Braga, just 92, or 16.7\%, included objects for Catholic worship. All of the rosaries were made from precious materials, indicating that they were more collectors' pieces than items for worship! ${ }^{34}$

Within the Portuguese area of influence, including Brazil, the Jewish religious-cultural heritage always remained alive. In addition to Jews coming from other European countries, who were attracted by the possibilities of enrichment in Brazil, the permanence of Jewish culture must be mainly attributed to members of the New Christian community, the Catholics who had been - or whose ancestors had been - Jews.

33 Mott L., Sexo Proibido, Virgens, gays e escravos nas garras da Inquisição (Campinas: 1989) 174 .

34 Braga I.M.R.M.D., Bens de Hereges: inquisição e cultura material Portugal e Brasil (séculos XVII-XVIII) (Coimbra: 2012). 
Religious dualism was typical of New Christians. In public, members of this community sought to present themselves as faithful followers of Christ and Christianity. At home, they maintained Jewish customs, namely, they observed the Sabbath and other Jewish festivities and holidays, and even said Christian prayers in a different way. In the In Genere session of the autos-da-fé of the Inquisition [a specific ritual of public presentation by penitents and those condemned by the Inquisition in the Iberian context], the accused were not just asked whether they observed religious holidays, but also if they ended the Our Father without saying Jesus' name, or the psalms of David without the Gloria Patri. ${ }^{35}$

Between 1703 and 1740, 325 New Christians born or living in Rio de Janeiro were arrested, of whom 167 were women and 158 were men. The need to hide their religion meant that their homes became the preferred location for the concealed practice of Jewish rituals, which were transmitted essentially by women. ${ }^{36}$ The male population was mobile and unstable, being made up of merchants, soldiers and men attracted by the allure of prospecting for gold or precious stones. Thus, the women often headed the household. ${ }^{37}$

The trials of the Inquisition abound with references to magic practices such as superstition, divination, or prayers with affective intentions. For this reason, such forbidden practices mainly occurred indoors. On their arrival in Brazil, the Portuguese sought to combat local rituals performed mainly by the pajés, quacks credited with supernatural powers over nature and believed to be in direct contact with terrible demons among Brazilian indigenous population. Nevertheless, the pajés continued their activities.

As had already occurred with the indigenous population, African slaves were also prohibited by the Portuguese from celebrating their traditional rituals. However, these prohibitions had few practical effects. The sin of heresy was a very real threat in a context marked by the constant juxtaposition of the supernatural world on the natural world. Magic and witchcraft were

35 Silva L.G.F., Heréticos e impuros: a inquisição e os cristãos-novos no Rio de Janeiro: século XVIII (Rio de Janeiro: 1995) 113.

36 Gorenstein L., "Cristãos-novos, identidade e Inquisição", WebMosaica revista do instituto cultural judaico Marc Chagall 4, 1 (2012) 40-49, here 47. For a more general account of this topic from the perspective of the Iberian Empires, see Gillitz D., Secrecy and Deceit: The Religion of the Crypto-Jews (Albuquerque: 2002).

Almeida S.C.C., $O$ sexo devoto 61-62. 
frequently the last means available for ascribing meaning to the unknown and the inexplicable. ${ }^{38}$

The highly miscegenated population of Brazil, recently catechized into the Roman Catholic Church and/or living at a distance from Church authorities, instead of adopting Catholic devotions and rituals and forgetting or deserting their own, followed both new and old, exaggerating the points of resemblance between the two. At times, they created new saints out of elements of the two religious traditions, mestizo saints.

Among the most popular objects of worship from Africa were mandingas or patuás, small bags from Mali which were used to carry verses from the Koran. Over time, these bags were also used to carry objects of Catholic worship such as consecrated hosts, stones from altars or pieces of paper with prayers in honour of St Mark and St Cyprian. These objects were credited with special powers to protect their owner from enemies and ferocious animals, as well as powers to further the owner's interests. ${ }^{39}$

These pouches also show that, over time, contact between the various separate imaginaries present in Brazil created a distinct cultural memory, both among the colonized people and among the colonizers. This process of syncretism continued in the face of opposition from the authorities. The calundus, syncretic and collective rituals involving music and dance, were the object of condemnation and interdiction, though these interdictions had little success. This ritual was generally believed to bring cures for physical and mental diseases and to help find lost objects and identify criminals, or to bring good luck in hunting, agriculture and in professional life in general. ${ }^{40}$

\section{$6 \quad$ Conclusions}

In conclusion, the eighteenth century was decisive in establishing Catholicism in Brazil, as shown by the houses and dwellings of the most virtuous Catholics. Among them, we note the beatas and families who performed religious rituals throughout the day. The profound religiosity of many families also had a

38 Reis M.V., "Os diversos mundos das práticas mágico-religiosas a partir das visitações do Santo Ofício à América Portuguesa (1591-1599; 1763-1769)”, Revista Ultramares Dossiê Inquisição Colonial 71 (2015) 34-6o, here 47.

39 Calainho D.B., Metrópole das Mandingas: religiosidade negra e inquisição portuguesa no Antigo Regime (Rio de Janeiro: 2000) 153 .

40 Daibert R., "A religião dos bantos: novas leituras sobre o calundu no Brasil colonial", Revista Estudos Históricos 28 (2015) 7-25, here 16-17. 
significant impact in terms of space - consider the saints' rooms and the private chapels - leading to the collection of a wide range of objects for devotional use. However, sin was also to be found in many houses. Daily routines and domestic interiors were replete with sacrilegious practices. This period saw an increase in syncretism, at times verging on heresy, in particular due to the ancestral presence of elements of Judaism and of indigenous religions and the Massive influx of African slaves.

\section{Bibliography}

Algranti L.M., "A hagiografia e o ideal de santidade feminina: o impacto da leitura de vidas de santos nos conventos do Brasil colonial", in Nizza da Silva, M.B. (eds.), De Cabral a D. Pedro: Aspectos da Colonização Portuguesa no Brasil (Oporto: 2001) 165-191.

Algranti L.M., "Famílias e Vida Doméstica", in Novaes F.A. - Souza L.M. (eds.), História da Vida Privada no Brasil, Cotidiano e vida privada na América portuguesa (São Paulo: 1997) 83-154.

Almeida S.C.C., $O$ sexo devoto: normatização e resistência feminina no império português, XVI-XVIII, Ph.D. dissertation (Universidade Federal de Pernambuco: 2006).

Baer W., A economia brasileira (São Paulo: $2009^{3}$ ).

Boschi C.C., Os leigos e o poder (São Paulo: 1986).

Braga I.D., Bens de Hereges. Inquisição e Cultura Material. Portugal e Brasil (séculos XVII-XVIII) (Coimbra: 2012).

Branco M.A.H.S.C., “Oratórios Mineiros D. José I: O tema cristológico nos objetos de devoção familiar produzidos entre o fim do século XVIII e início do XIX", in Atas do IV Congresso Internacional do Barroco Ibero - Americano (Belo Horizonte: 2008) 1056-1061.

Calainho D.B., Metrópole das Mandingas: religiosidade negra e inquisição portuguesa no Antigo Regime (Rio de Janeiro: 2000).

Conceição Francisco da, Director instruído ou breve resumo de mística teologia para instrução dos directores (Coimbra, Na Real Imprensa da Universidade: 1779).

Constituiçoens primeyras do Arcebispado da Bahia feytas, \& ordenadas pelo Illustrissimo, e Reverendissimo Senhor D. Sebastiaõ Monteyro da Vide, Arcebispo do dito Arcebispado, \& do Conselho de Sua Magestade, propostas, e aceytas em o sinodo Diocesano que o dito Senhor celebrou em 12. de Junho do anno de 1707 (Lisboa, Officina de Paschoal da Sylva, impressor de Sua Majestade: 1719; reprint, São Paulo: 1853).

Cunha M.S., Estórias de dor esperança e festa: o Brasil em ex-votos Portugueses (século XVII-XIX) (Lisbon: 1998). 
Daibert R., "A religião dos bantos: novas leituras sobre o calundu no Brasil colonial", Revista Estudos Históricos 28 (2015) 7-25.

Del Priore M., "Ritos da vida privada", in Novais F.A. - Souza L.M. (eds.), História da Vida Privada no Brasil, Cotidiano e vida privada na América portuguesa (São Paulo: 1997) $275^{-330 .}$

Eisenberg P.B., The Sugar Industry in Pernambuco: Modernization Without Change, 1840-1910 (Berkeley 1974).

Franco João, Mestre da vida, que ensina a viver, e morrer santamente (Lisbon, Na Regia Officina Typografica: $\left.175^{\circ}\right)$.

Gillitz D., Secrecy and Deceit: The Religion of the Crypto-Jews (Albuquerque: 2002).

Gorenstein L., "Cristãos-novos, identidade e Inquisição", WebMosaica revista do instituto cultural judaico marc chagall 4, 1 (2012) 40-49.

Jancsó I., "A sedução da liberdade: cotidiano e contestação política no final do séc. XVIII", in Novaes F.A. - Souza L.M. (eds.), História da Vida Privada no Brasil, Cotidiano e vida privada na América portuguesa (São Paulo: 1997) 388-437.

Lima H.L. - Castro R.R., "O imaginário da cristandade no Rio de Janeiro do século XIX nas pinturas de Rugendas e Debret”, $19 \& 204$ (2009), http://www.dezenovevinte.net/ obras/obras_cristandade.htm; accessed 8 July 2016.

López R.L., "Family Religiosity and Images in the Home: Eighteenth-Century Puebla de Los Angeles, México", Journal of Family History 22, 1 (1997) 26-49.

Luccock J., Notes on Rio de Janeiro and the Southern parts of Brazil: taken during a residence of ten years in that country, from 1808 to 1818 (London: 1820).

Mathison G.F., Narrative of a visit to Brazil, Chile, Peru and the Sandwich Islands during the years 1821 and 1822 . With miscellaneous remarks on the past and present state, and political prospects of those countries (London: 1825).

Mott L., "Cotidiano e vivência religiosa: entre a capela e o calundu" in Novaes F.A. Souza L.M. (eds.), História da Vida Privada no Brasil, Cotidiano e vida privada na América portuguesa (São Paulo: 1997) 156-220.

Mott L., Sexo Proibido, Virgens, gays e escravos nas garras da Inquisição (Campinas: 1989).

Oliveira A.C., "A difusão da doutrina católica em minas gerais no século XVIII: análise das pastorais dos bispos", História: Questões \& Debates 36 (2002) 189-217.

Pereira Nuno Marques, Compendio narrativo do peregrino da america em que se tratam varios discursos Espirituaes, e moraes, com muitas advertencias, e documentos contra os abusos, que se achão introdusidos pela malicia diabolica no Estado do Brasil. Dedicado à Virgem da Vitória, emperatris do ceo, rainha do mundo, e Senhora da Piedade, Mãy de Deos, 2 vols. (Lisbon, Officina de Manoel Fernandes da Costa, Impressor do Santo Officio: 1728; reprint, Lisbon: 1939). 
Reis M.V., "Os diversos mundos das práticas mágico-religiosas a partir das visitações do Santo Ofício à América Portuguesa (1591-1599; 1763-1769)", Revista Ultramares Dossiê Inquisição Colonial 71 (2015) 34-6o.

Rowe E., "Visualizing Black Sanctity in Early Modern Spanish Polychromic Sculpture", in Patton P.A. (ed.), Envisioning Others: Race, Color, and the Visual in Iberia and Latin America (Leiden - Boston: 2015) 51-82.

Russell-Wood, A.J.R., "The Gold Cycle, c. 1690-1750", in Bethell L. (ed.), Colonial Brazil (Cambridge et al: 1987) 190-243.

Santa Maria Agostinho de, Santuario Mariano, e Historia das Image [n]s milagrosas de Nossa Senhora, e das milagrosamente apparecidas, em graça dos Prègadores, \& dos devotos da mesma Senhora, 20 vols. (Lisbon, Na Officina de Antonio Pedroso Galrão 1707-1723; reprint, Lisbon: 1933).

Scarano J., Fé e milagre: ex-votos pintados em madeira: séculos XVIII e XIX (São Paulo: 2004).

Silva B.N., Cultura e Sociedade no Rio de Janeiro (1808-1821) (São Paulo: 1977).

Silva L.G.F., Heréticos e impuros: a inquisição e os cristãos-novos no Rio de Janeiro: século XVIII (Rio de Janeiro: 1995).

Silveira J. de S.J.Q. da, "Viagem e Visita do Sertão do Bispado do Gram Pará em 1762 e 1763", Revista do Instituto Histórico Geográfico 9 (1847) 43-107, 179-227, 328-375, 476-527.

Siqueira S.A., A Inquisição portuguesa e a sociedade colonial (São Paulo: 1978).

Souza L.M., "Formas provisórias de existência: a vida quotidiana nos caminhos, nas fronteiras e nas fortificações”, in Novaes F.A. - Souza L.M. (eds.), História da Vida Privada no Brasil 1997 (São Paulo: 1997) 42-81.

Vianna H., A Bahia já foi assim (crônicas de Costumes) (São Salvador da Bahia: 1973). 